\title{
A Reinterpretation of Hindu Spirituality for Addressing Environmental Problems
}

\author{
Ashutosh Awasthi
}

check for updates

Citation: Awasthi, Ashutosh. 2021.

A Reinterpretation of Hindu Spirituality for Addressing Environmental Problems. Religions 12: 358. https://doi.org/10.3390/ rel12050358

Academic Editor: Christopher Key Chapple

Received: 4 April 2021

Accepted: 13 May 2021

Published: 18 May 2021

Publisher's Note: MDPI stays neutral with regard to jurisdictional claims in published maps and institutional affiliations.

Copyright: (C) 2021 by the author. Licensee MDPI, Basel, Switzerland. This article is an open access article distributed under the terms and conditions of the Creative Commons Attribution (CC BY) license (https:/ / creativecommons.org/licenses/by/ $4.0 /)$.
Department of Environmental Science, Teerthanker Mahaveer University, Delhi Road, Buddhi Vihar Phase 2, Moradabad 244001, Uttar Pradesh, India; ashuaw@yahoo.in; Tel.: +91-0591-236-0500

\begin{abstract}
Global environmental change is a serious threat to our existence and requires immediate actions from every dimension of our efforts. The cultural pathway has much potential to address environmental problems because it is expected to promote environment-friendly behavior in people. However, its implementation on the ground requires a wise coordination of the cultural and scientific ways of thinking. Hinduism has great potential to embrace environment-friendly behavior due to its receptivity to change and tendency of adopting and theologizing new developments. However, due to the presence of a wide gap between theoretical philosophy and actual practices, the potential of environmental sensibility, inherent in Hindu spirituality, could not be harnessed. Here, I reinterpret the key concepts of Hinduism in the light of modern scientific wisdom for their synchronization with current challenges. I identify some solutions for promoting environment-friendly practices in Hinduism through the coordination of science and culture.
\end{abstract}

Keywords: environmental problems; Hinduism; spirituality; dharma; sustainable

\section{Introduction}

The anthropogenic degradation of life-supporting environments requires serious actions from every dimension of our efforts (Steffen et al. 2018; IPCC 2018). Religions can play important roles in addressing global environmental change by influencing peoples' views and behavior (Hitzhusen and Tucker 2013; Dasgupta and Ramanathan 2014; Morrison et al. 2015; Taylor et al. 2016; Chaplin 2016). Religions can explain the moral ground of environmental problems and promote environment-friendly practices in society. The concepts present in various religious philosophies like stewardship of nature, kindness to god's creation, climate justice, holiness of nature, etc. have abundant potential to moderate people's behavior (Jenkins et al. 2018). Environment-friendly traditions and rituals that promote good dietary habits and the efficient use of resources can significantly contribute to reducing greenhouse gas emissions and environmental degradation (Tilman and Clark 2014; Godfray et al. 2018; Springmann et al. 2018). Interpretations of environmental problems in statements of various religions explain how environmental problems like climate change are important for a community, and how different religions have the potential to be greener. However, there are many inconsistencies between the original concepts and ground practices in different religions, which hinders the harnessing of the potential of religious pathways in addressing environmental problems (Shinde 2011). A wise coordination of religion and science requires bridging these gaps through the engagement of scientists and non-scientists who can exchange their ideas honestly and effectively with each other (Hitzhusen and Tucker 2013). However, the explanation of environmental problems with a religious point of view without their scientific degradation and the assimilation of religious responses into public policy remain challenging (Grim and Tucker 2013; Jenkins et al. 2018).

With more than a billion adherents, Hinduism has a huge share in global environmental problems. In various contexts, Hinduism is considered as a religion; however, it is a way of life containing many religious entities widely practiced in the Indian subcontinent. Hinduism has many unique features like receptivity to change, acceptance, and the 
incorporation of diverse ideas from different sources, which offers an opportunity for its alignment with timely needs and the development of nature-based spirituality (Miller 1977; Srinivas 2004; Haigh 2010; DeNapoli 2017). Worldwide efforts are being made to interweave environment-friendly values into religions through restructuring their pre-existent worldviews, attitudes, practices, rituals, and traditions, which can improve people's attitude and behavior toward nature. Here, I interpret the central concepts, worldview, beliefs, and vocabularies of Hinduism in the light of modern scientific understandings and explain the basic questions related to the Hindu worldview like who am I and what is the purpose of my life, the relation of other forms of life with human beings, etc. I will strive to develop a religious imagination and interpretation of environmental problems like climate change and search the possible ways of harnessing the potential of Hinduism for addressing such problems through the coordination of religion and science.

\section{Reinterpretation of Some Basic Concepts of Hindu Worldview}

Hinduism is understood as a way of life with a diversity of overlapping philosophies, concepts, and practices. Hinduism lacks consensus on any of these and the traditions of questioning and debating everything are inherent. In the following paragraphs, I attempt to discuss some central concepts of Hinduism in the light of scientific understandings.

\subsection{What Is the Ultimate Reality?}

"Sarvam khalvidam brahma" (everything that has existence is Brahman; Chhandogyopanishad).

According to the philosophy of Hinduism, the ultimate reality of everything is the Brahman. It is attribute-less (nirgun: its attributes cannot be defined or it has all the imaginable attributes), formless (nirakar: its form cannot be defined or it has all the imaginable forms), infinite (anant), and omnipresent (sarvabyapi). It may be argued that the concept of Brahman is the same as the scientific concept of 'Nature'. There is no standard definition of Nature in science and different discourses converge on the same line that "everything that has existence is Nature" (Ducarme and Couvet 2020). Different types of living and non-living forms develop, eliminate, and again get assimilated into the Brahman. Its current form on Earth contains human civilizations along with other living and non-living entities known as the environment of Earth.

All living and non-living entities are parts of the environment and made of the same types of substances (chemical elements). These elements are interchanged between the living and non-living components of the environment through nutrient cycling. According to the Advait (non-dualism) philosophy, there is no basic difference between living and non-living matter. As the non-living entities have their specific attributes (defined by physical and chemical properties), living beings also have similar, except a unique attribute known as life (defined by biological properties). Like nature, life also lacks a unanimous definition. It is the biological functioning of a system that makes an entity living and whose failure makes the same entity non-living (Ma 2016).

\subsection{Who Am I?}

In Hindu spirituality, the true self of an individual is known as Atman. It is the essence or nature of a living being and the consciousness (or basic functioning) of life. The Atman is similar (but not identical) in all living beings. According to scientific understanding, basic functioning of life is similar in all life forms. All life forms have developed from a universal common ancestor and thus are related to each other (Theobald 2010). Similar conclusions are drawn in Hinduism because all life forms are the manifestations of similar Atman. By definition, the Brahman as well as the Atman are both Nature. The central concept of Advait philosophy is the non-duality of Atman and Brahman (Sharma 2007). This concept is reflected in the famous maxim (Mahavakya) of Brihadaranyaka Upanishad; "Aham Brahmasmi", I (Atman) am the Brahman (Nature). In this way, Hinduism assumes no difference between different types of life forms, including humans. 
The behavior of living organisms is the result of the interaction of their genetic makeup and the effect of their living environment. Behavior according to genetic predispositions is called 'nature' and the behavioral traits that develop due to environment like rearing, experience, etc. are called 'nurture'. Nature is genetically fixed and not subject to change; however, the properties influenced by the environment can be controlled and changed. The genetic makeup of organisms is evolved for their survival and reproduction in their living environments. In higher animals, genes affect behavior through the incitement of positive and negative sensations. Behavioral traits beneficial for survival and procreation like eating, mating, etc. are often naturally associated with pleasure and noxious behaviors that are harmful are associated with pain (Nesse and Williams 1996; Balcombe 2009). In other words, it is animals' nature to avoid the pain and increase the reward of pleasure. Human nature is also not an exception of this biological phenomenon (Grinde 2004). In Hindu spirituality, the subjective experience of Brahman as well as Atman is assumed to be blissful, which is known as Sat-chit-ananda (sustainable happiness; Jones and Ryan 2006).

The behavior of different individuals of a species can also vary according to their nurture, such as, exposure, experiences, and learning. However, this behavioral plasticity is limited in non-humans. Most of the behavior of non-human animals is according to their nature, and the actions and the consequences of such actions are considered natural phenomena. The effect of nurture is more pronounced in humans than other animals due to the presence of advanced cognitive ability. This inherent plasticity in human behavior enables us to control our natural instincts (nature), which distinguishes us from other animals (Suddendorf 2013). The extreme of this control is the assumption that the human cognitive process is entirely independent of nature (known as free will). A significant proportion of human nurture is based on learning to control the natural instincts for developing various social norms and civilized behavior. Self-control is imparted as a prerequisite for achieving desired material as well as spiritual success in life. Children are systematically subjected to various types of (social and corporal) conditioning for developing different sets of prejudices, beliefs, standards, and identities, and are supposed to follow certain conventions required for achieving traditionally defined success in life. However, we are not exempt from the influence of our nature. Various aspects of the traditional course of life may be rewarding or punishing depending on whether these aspects supplement or reduce the effects of our innate predispositions. Under the influence of such conditioning, many of us choose to behave in a way that is against our nature, such as accepting a profession for which we are not motivated or maintaining many relationships and playing roles that we do not like. As a result, opposite to our nature of pursuing happiness, we may accept punishment instead of reward. In Hindu spirituality, it is known as an imaginary world of ignorance (Samsar) fabricated by Maya or Adhyasa. Due to ignorance, we fail to realize our true self, the Atman, whose subjective experience is rewarding. This deviation from true nature has created the false perception that human beings are different from Nature. According to Hindu spirituality, perceiving Atman as different from Brahman is the root of all the problems and sufferings.

\subsection{What Is the Aim of My Life?}

Scientifically, life has no specific aim. The instant tasks of living beings are directed by their nature, i.e., to do that which is rewarding and avoid that which is painful. According to Hindu spirituality, there are four objects (not aims) of human pursuit (known as Purusharthas), Dharma (proper behavior), Artha (prosperity), Kama (pleasure), and Moksha (liberation). The first three purusharthas, dharma, artha, and kama, are known as the essential objects of life (Trivarga; the essential three). Dharma is the way of securing artha and artha is the means of kama. Therefore, the kama may be viewed as the final object and it includes all the pleasures of life (fulfilment of desires, wish, passion, longing, pleasure of the senses, aesthetic enjoyment, affection, love, etc.). The trivarga are considered animalistic or materialistic objects because these are not unique to humans but simply an extension of animal life. 
The fourth object, moksha (also known as Apavarga, the other objective), addresses the problems of human origin like higher levels of positive and negative feelings, questioning about reality, self, etc. These are the byproducts of enhanced cognitive ability and are also known as spiritual anxiety. It can be argued that it provides spiritual contentment or pleasure by addressing these questions and enhances the degree of materialistic pleasure by bringing perfection in trivargas (Figure 1). As the bondages of ignorance are cut, we can realize our dharma in the better way (Text Box 1), which leads to more artha and thereby enhances the kama. On complete liberation, the full potential of dharma secures unlimited sources of artha and the degree of kama, supplemented by spiritual pleasure, extends to the maximum, i.e., the realization of sustainable happiness (sat-chit-ananda).

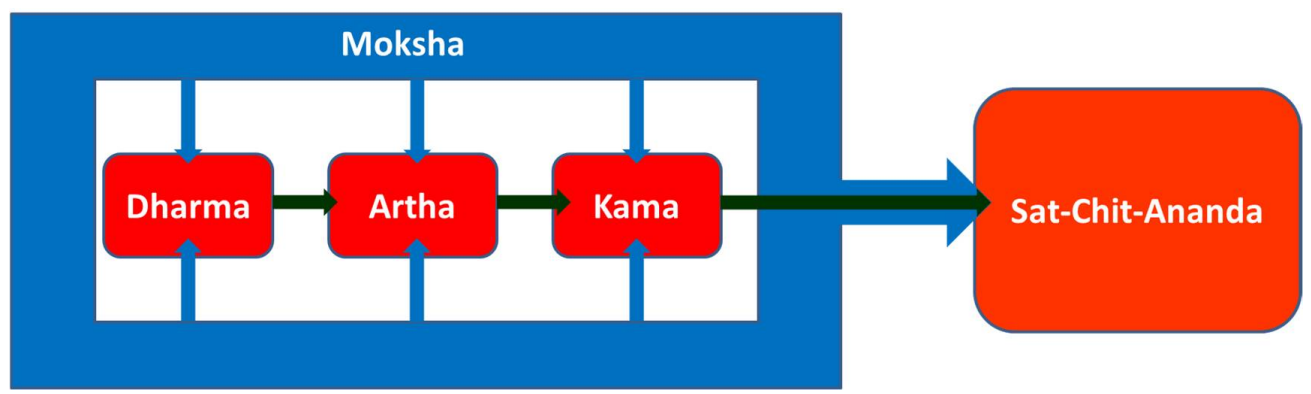

Figure 1. Purushartha: the four objects of life (please see text for description). Dharma is the way of securing artha and artha is the means of kama. Dharma, artha, and kama are the essential objects of life. Moksha clears ignorance and enhances the capability of realizing the other three (mainly dharma) to their full potential. On achieving complete moksha, the other three can be realized to the maximum, which leads to the extension of the pleasure of life (kama) to the Sat-Chit-Ananda (sustainable happiness).

\subsection{There Are Two Ways to Realize the Dharma: Gyan and Bhakti}

According to Hindu spirituality, there are two ways to realize the Dharma: Gyan marg (the path of knowledge) and Bhakti marg (the path of faith). Gyam marg is the rationalistic way where no divine intervention is required. One may realize Swadharma by his/her own wisdom. Continuous effort for moksha by knowledge sharpens the power of wisdom and further enhances the capability of realizing the dharma. On the other hand, the Bhakti marg requires unfettered devotion to god and Guru (teacher). Moksha is generally not required in this path because the guru guides the realization of pupils' dharma. Only this aspect of Hinduism can be called a religion and compared to other religions of the world.

Knowledge is the awareness and understanding of the self and the environment for finding the solutions of various problems. It can be acquired by self-experience or getting instructions from a guru (Rigopoulos 2018). The followers of gyan marg are generally enquirers who have the ability of understanding and critical thinking about the knowledge accumulated from different sources. Although the knowledge has no boundaries, the general practices of gyan marg are to strive for self-awareness (what is all around, who am $\mathrm{I}$, what is the aim of my life, what is my dharma, etc.), and developing personal (Niyamas) and social skills (Yamas) for sharpening one's own capabilities. Only the knowledge of scriptures is not the gyan. For example, views postulated in Indian philosophy were developed centuries ago; however, the world of knowledge is changing every movement. Although there is a little change in basics, the same basic problems can be explained in a better way as new knowledge comes to light from many sources. Following the gyan marg is not only acquiring the knowledge or possession of an ability of critical thinking. It needs the realization of such knowledge and its reflection in the follower's behavior. The knowledge that is not reflected in action is futile, as the knowledge of various techniques of physical exercise does not make one fit without continuous practice. For example, the non-dualism of atman and brahman can be well explained with principles of environmental science, astrophysics, biology, etc. The knowledge of setting proper goals and the process of execution paves the way to success and a happy life. 
Box 1. Dharma and Moksha.

Etymologically, the Dharma is derived from the root 'dhr' meaning 'to sustain'. It is often interpreted as righteousness, duties, virtues, the right way of living, etc. Ancient scriptures define the dharma with two properties. First, it is eternal (Sanatan) and, second, it leads to both materialistic and spiritual successes ("Yato Abhyudaya Nishreyas Siddhi Sa Dharma"). According to Hindu spirituality, the divide of materialistic and spiritualistic is artificial. Both types of successes complement each other to maximize happiness. Like other animals, we are also naturally wired to grasp natural rewards and avoid pain. Animals' behavior is generally instantaneous with little planning. However, humans are not satisfied with instant rewards. Enhanced learning ability and nurturing environment provides us with the capacity for future planning. We strategically plan for maximizing our reward for a longer period, even sacrificing smaller rewards to achieve bigger rewards. The capacity for strategizing is different in different individuals according to their nature and nurture. A higher strategizing capacity enables an individual to plan further into the future. However, how far out should we plan?

The concept of Punarjanma is one of the most misunderstood concepts in Hinduism. It is assumed to be the repeated rebirth or reincarnation of the same individual after death. However, it specifies the continuity of life. According to the concept of punarjanma, life does not start with birth and end with death. Parents are considered the previous manifestation (janma) of children and children are the next manifestation (janma) of parents. The concept of punarjanma is closely related to the concept of Karma-Phal, which states that karmas (actions) never destroy. The consequences of meritorious karmas (punya) are rewarding while the consequences of bad karmas (papa) are painful. The consequences of good or bad actions, done in any condition, have to be borne by the actor. The credit or debt of actions done in previous janma can be carried to the next janma. Children's early survival, health, education, and most of their behavior is shaped by parents' actions and socioeconomic legacy (social reputation and economic status). Therefore, an ideal strategy is to maximize pleasure for eternity, or realize sustainable happiness (Sat-Chit-Ananda). The strategy that ensures sustainable happiness is known as Sanatan dharma.

Sanatan dharma is an ideal strategy for realizing sustainable happiness. Its realization by people extends from minimal, the behavior of ignorant people, to maximal, for those who have attained the moksha. Dharma is an individualistic concept expressed as Swadharma (self-dharma). The Dharma of different people is different, which depends on varying conditions of space and time. In normal conditions, the prosocial behavior that is considered virtuous or righteous (truth, non-violence, helping, sharing, donating, co-operating, and volunteering) is according to dharma. However, none of these characters is the essential component of dharma. In rare cases, all of these can also be violated to uphold the dharma of some people in society. As our genetic makeup is aimed at our own fitness, not that of others, our dharma focuses on enhancing our own happiness, not that of others.

For obvious reasons, enhancing the happiness of family and friends is the our dharma. The group of people bound by a common cause like family and friends is known as Kutumb. In kutumb, the happiness of each member of the group is shared. It is the dharma of each member of kutumb to ensure that the other members behave according to their dharma ("Ishtam darmen yojyet": Own people should be joined with dharma). Ignoring the actions of others is not according to dharma because the karma and consequences are shared among the members of kutumb. The aspect of dharma of people that is shared with the whole Kutumb simply becomes 'the dharma in itself' (here I distinguish it as DHARMA). Swadharma is considered from an individualistic point of view while the DHARMA is considered by its own cause. The doer is not important in the case of DHARMA; only the maintenance of DHARMA is essential. The dharma of individuals is to ensure that the DHARMA is being maintained in the kutumb. The consequences of the degradation of DHARMA by the behavior of any member have to be borne by all members of the kutumb. Global problems like climate change are perceived with the concept of "Vasudhaiva Kutumbakam," (the whole world is one kutumb). However, the realization of Vasudhaiva Kutumbakam needs the people of the whole world to behave like kutumb, i.e., everyone should monitor everyone's actions.

We can realize our dharma best when we act according to our natural calling (and do not behave against our nature). However, most people cannot realize their dharma beyond a certain limit due to many limitations like personal weaknesses, prejudices, beliefs, etc. (known as the bondages of Maya or Adhyasa). Although these bondages are false like monkey traps (Note 1$)^{1}$, they seem real and strong due to Maya. Becoming free from these false bondages by cutting them with wisdom and the realization of their own true self is known as the Moksha. The realization that I, the atman, am inseparable from parmatman is moksha. The Moksha helps us in identifying our Atman so that we can behave according to our nature. Like Dharma, Moksha is also an ideal condition. Achieving Moksha is a continuous process in life. It removes the obstacles of ignorance and guides the proper dharma that leads to an unrestricted full human potential for achieving sustainable happiness (Klostermaier 1985). 
The bhkati marg is the process of developing unfettered faith in god and following the teachings of a guru. The followers of this line submit all their actions to their guru. The importance of the guru is very high in bhakti marg. It is sometimes considered even higher than god (Rigopoulos 2018). In bhakti yoga, developing love and devotion to god is assumed as the dharma of followers (known as bhakti). Bhaktas do not worry about the moksha but want to be a part of god. Ideally, these gurus are the followers of gyan marg, who have the ability to explain the complicated problems of life and their solutions in a language understood by masses.

\subsection{Both the Ways Unite in Action}

Religious and secular ideas are intricately entangled in Hindu spirituality. Regardless of our perception, these are the actions that make change in the world. Both gyan and bhakti can unite in actions in Hinduism. The behavior adopted by the followers of Gyan after rigorous analysis is trailed by the followers of Bhakti without the knowledge of such exercises. Whether people follow vegetarianism with a clear understanding of climate science or they are influenced by religion, it will make the same impact on the environment. This is the reason why the champions of gyan marg like Adi Shankaracharya did not criticize the bhakti but promoted it when required. Animals take food for their own gratification not considering its nutritive value but their digestive system unknowingly extracts its nutrition for their nourishment. Similarly, gurus influence people's actions for maintaining the DHARMA in society through cultural interventions without imparting the abstract knowledge of scientific concepts. Gurus affect every aspect of the life of devotees by the ritualization of desired behavior. They can start new healthy traditions, modify existing ones that are distracted, and discontinue those that are no longer relevant in the present time (Lucia 2014). Gurus work as role models for their followers. They theologize the abstract concepts of knowledge for common people and develop the customs, traditions, and values through entangling it with religious philosophy (Miller 1977). Traditions and rituals are often integrated in peoples' identity and preserved in societies for a long time. Many corporations ritualize consumers' behavior to make them more excited about their products and enhance consumption (Vohs et al. 2013). Religious ritualization can bring remarkable changes that are otherwise difficult. The instructions obtained by trusted and reputed people can affect people's behavior, especially when such messages are delivered in a package of religious beliefs and social norms (Cinner 2018). Traditions like vegetarianism, respect for the austere, and nature worshiping developed thousands of years ago for several reasons and are still practiced in many forms in Hinduism. These traditions did not develop in response to environmentalism or in a lack of resources, but emerged in the environment of excess and in affluent societies with a higher standard of living (Baumard et al. 2015). It was observed that the demand for meat with the increasing economic status of people in India does not increase as fast as in other parts of the world due to religious reasons (Tilman and Clark 2014; Godfray et al. 2018). In this way, the coordination of science and religion by Gurus has a great potential to promote healthy actions in society.

\subsection{What to Do with These Concepts for Addressing the Global Change}

The coordination of religious beliefs and scientific wisdom is deeply embedded in Hindu spirituality. It has the great potential to address environmental problems. However, as in other cultures, the theoretical frameworks present in philosophies and theologies may not be adopted by followers in their intact forms. There are many inconsistencies between philosophy and actual practices in Hinduism (Shinde 2011; Tomalin 2004). Despite numerous environment-friendly practices and deep underpinnings of environmental sensibility, India, where Hindus are the majority, is facing serious environmental problems, such as immense air pollution (Ravishankara et al. 2021; Sathe et al. 2021), the mismanagement of hazardous solid waste (Karthikeyan et al. 2018), etc. Without bridging this gap, a motivation of environmental care cannot be developed in society. Practices can deviate from original theory due to misinterpretation of principles or willful neglect by people because 
of their personal weaknesses. Most of the practices in Hinduism developed centuries ago when there was no perception of environmental problems like today. Animal sacrifice, bathing, cremating bodies at riverbanks, and scattering the worshiping material and ashes into the rivers, etc. may not have been a serious problem when the human population was very low and scattered. However, such practices became critically harmful due to the great increase in population and rapid industrialization. Such practices need to be addressed in novel ways by integrating modern developments into religious traditions. Hinduism is highly receptive to change. It has an immense capacity for synchronizing itself with new developments. Religious workers continuously accept and theologize novel technologies and concepts in Hinduism (DeNapoli 2017). Here, I propose some solutions for gyan and bhakti margs for bridging the gaps between theory and practice.

\subsection{Solutions for Gyan Marg}

The environment is the source of all the aspirations of life and maintaining environmental sustainability is the DHARMA. We have already degraded the environmental conditions and are bearing the consequences of our own actions. The followers of gyan marg are expected to uphold the DHARMA by their own actions, as well as watching and influencing others when required. However, in many cases, intellectuals can also divert people's behavior from DHARMA for many motives (known as Brahmrakshas, the Gyanis who misuse their knowledge to do evil things). Knowledge has become highly specialized in the present time. People specialized in a subject may not have sufficient knowledge and understanding of other dimensions because they are never exposed to that education. To address environmental problems, we need to develop a proper curriculum of environmental spirituality covering elementary knowledge of environmental science and related concepts of ecology, evolution, philosophy, social science, etc. It will be useful for the followers of gyan marg and for providing training to religious gurus. Many gurus have remarkable knowledge of spirituality and materialism (Rigopoulos 2018). Such gurus may be willing to incorporate environmental spirituality in their discourse and communicate it to their followers by various means (DeNapoli 2016). Studies suggest that imparting environmental education in Hindu societies may result in positive changes in peoples' lifestyles (Chauhan et al. 2009, 2010)

\subsection{Solution for Bhakti Marg}

The theoretical framework of Hinduism developed through centuries in various philosophies and theologies that are highly entangled with each other. Hinduism is a decentralized spirituality. It has no central command or a model code of conduct that is strictly followed. The religion is practiced in numerous traditions and rituals, which continuously originate, change, and extirpate through time. This plasticity provides an opportunity to synchronize religious practices with new developments, like starting new traditions and rituals that are useful and discontinuing or modifying the existing ones that are no longer relevant or are harmful in the current scenario. The intervention of gurus, who have the responsibility to set the traditions and rituals according to DHARMA, is very important for a better coordination of gyan and bhakti. Here, I identify some ways through which environment-friendly practices can be promoted in Hinduism: (a) the religious explanation of environmental problems; (b) the encouragement of good religious practices by their interpretation with modern scientific knowledge; and (c) reformation of the practices that have deviated from the original concept and discontinuing the bad practices.

(a) Religious explanation of environmental problems

Environmental problems can be religiously explained in Hinduism by the reinterpretation of its preexisting components to align them with current developments. In Hindu theology, the brahman is known as parmatman (grand soul) and personified as Vishvarupa god or Lord Vishnu (Figure 2a). Vishvarupa god has infinite forms and we are the part of the current form of god that is Earth's present environment. Anthropogenic activities are clearly degrading the DHARMA because these are eliminating innocent lives and wound- 
ing the body of Vishvarupa god. When at least a few people perceive the loss of DHARMA, they pray to Lord Vishnu. In many contexts of Bhagvat Puran and Ramayana, Mother Earth has also been personified and shown as praying to the Lord that she cannot hold the burden of such loss of DHARMA. The Lord manifests himself in some great personalities (known as Avatars) who maintain the DHARMA by performing extraordinary works. Since every atman is the fraction of brahman, everyone is a potential avatar. It explains that the nurturing environment nurtures the self in a religious way and encourages people to take actions to uphold the DHARMA. However, when the DHARMA declines to a great extent and people are unwilling to address the problem, the Vishvarupa God changes its form, known as Pralay (the great deluge, shown as the sea level rise as proposed in the effect of global warming). If we want to maintain our existence, we must uphold the DHARMA. Worship according to DHARMA is the respectful nurturing of every fraction of the Vishvarupa god and the restoration of the loss that has been already incurred. The traditions and rituals of religion must be aligned with this concept of worshiping. Several religious groups are already incorporating environmental consciousness in their religious activities (Luthy 2019).

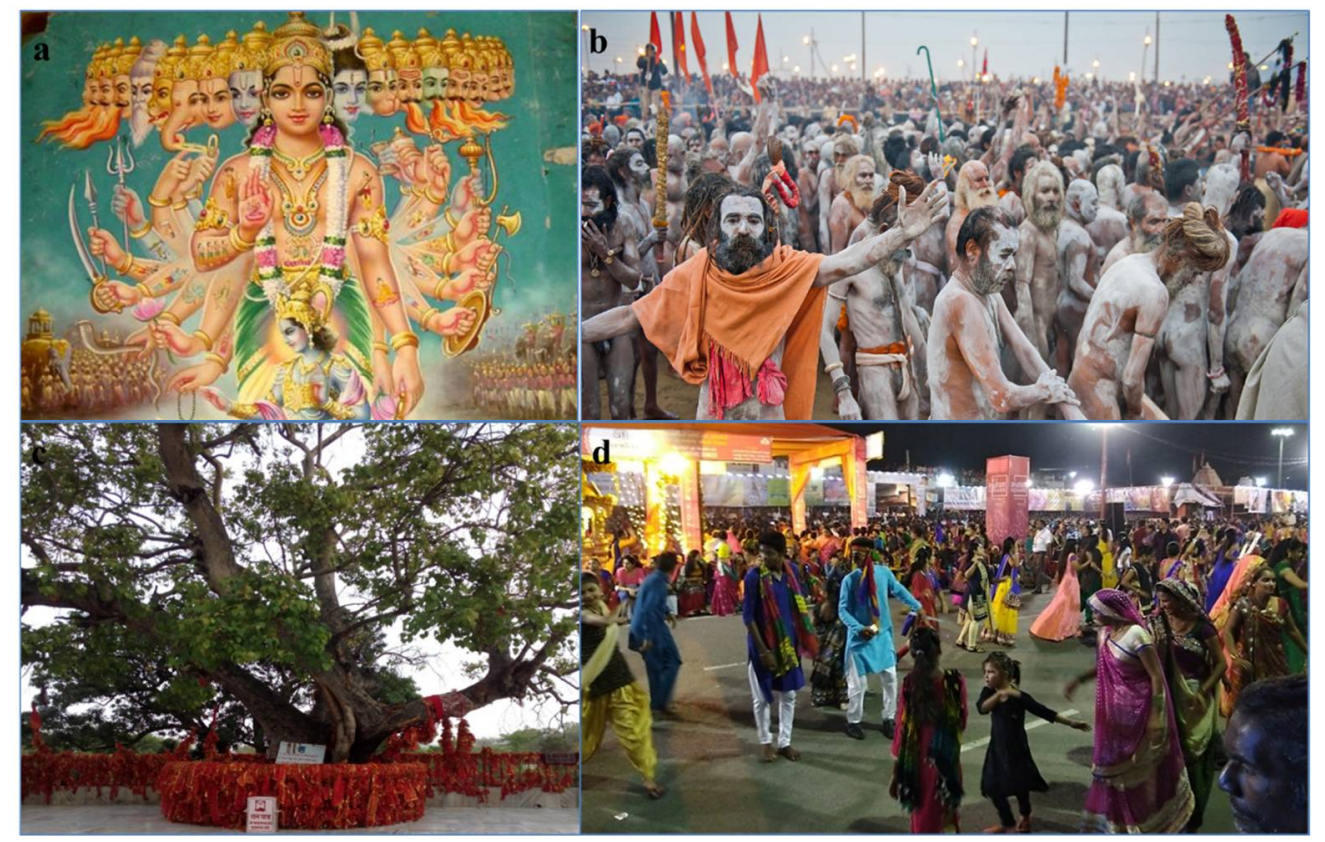

Figure 2. Hinduism has much potential to impart environmentally-friendly practices in people through religious pathways: (a) An artist's image of Vishvarupa god; (b) thousands of ascetics (e.g., Naga Sadhus) voluntarily sacrifice the amenities of regular life and reproduction in many cases and live on minimal resources; (c) many plants like Peepal, Banyan, Neem, etc. are worshipped by Hindus who avoid cutting these trees; (d) religious fasting is prevalent in Hinduism. Navratri (nine days fast) is one of the most celebrated fasts, which occurs two times in a year. Photo: (a,c,d) from Wikimedia commons; (b), by Mr. Abhisek Hajela.

(b) Encouragement of good religious practices by their interpretation with modern scientific knowledge

India harbors a huge population of vegetarians, ascetics, and nature worshippers. Although the environmental goodness attached to these traditions is the byproduct of religious psychology, the contribution of such practices to environmental health is clear. The encouragement of good practices with scientific recognition and explanation can boost the morale of traditional practitioners and encourage others who are leaving these habits by thinking them non-compatible with modernity. The following are some areas where environment friendly habits can be encouraged by religious and intellectual interventions. 
Modifying dietary habits: Vegetarian diets have comparatively lower environmental footprints and health risks than non-vegetarian ones, and shifting toward vegetarianism can reduce environmental risks like greenhouse gas emissions and deforestation (Tilman and Clark 2014; Rust et al. 2020). Many Hindus do not eat meat in their lifetime. Days like Tuesday, Thursday, Ekadashi (the eleventh lunar day of every lunar month in the Indian calendar), and other numerous festivals are associated with various Gods and treated traditionally as non-meat-eating days. India is an exception to the global trends in which the consumption of meat does not increase with growing socioeconomic status of people (Sans and Combris 2015; Fourat and Lepiller 2017; Godfray et al. 2018; Ferry 2020). Now, vegetarian traditions are being started in many societies, with climate change movements such as 'Meatless Monday', 'Veggie Thursday', etc. However, such types of traditions are already present in Hinduism with a strong religious base. The promotion of such traditions by scientific recognition and public policies can highly contribute to our efforts of addressing environmental problems.

Reducing consumption: A consumer lifestyle leads to the overexploitation of natural resources and the degradation of the environment's capacity to support life (Rockström et al. 2009). Hindu spirituality discourages overconsumption and the blind accumulation of wealth. Renunciation is most admired as a stage of life and is still common in Hinduism, where ascetics live on minimal resources after renouncing the luxuries of life (DeNapoli 2017; Figure 2b). These people contribute to the conservation of resources and prevent biodiversity loss unknowingly through religious pathways. Religious fasting is prevalent in Hinduism. Many people practice weekly fasts on specific days like Monday, Tuesday, and Thursday that are dedicated to various gods. Numerous festivals like Navratra (nineday fast, occurs two times in a year), Ekadashi, Chhath Puja, etc. are highly celebrated fasting days (Figure 2d). Research shows that most of these traditions developed in affluent societies in the environment of excess, not in response to the lack of resources in Hinduism (Baumard et al. 2015). In this way, the religion is reversing the natural trends of consumption where people consume less with an increase in socioeconomic status. The encouragement of such religious traditions has the potential to reduce overconsumption in Hinduism.

Moderating personal behavior through moralizing Gods: Personal behaviors like eating meat or not and living a simple or luxurious lifestyle cannot be regulated without the unwanted degradation of some essential freedom of society. The existence of an ultimate controller, i.e., omnipresent, almighty god, may moralize the behavior of believers by appearing to punish the miscreants and facilitate the moral practitioners (Roes and Raymond 2003). People behave differently when they assume that they are being watched (Cinner 2018). The concepts of moralizing Gods are widespread in many religions, which promote moral attributes like compassion, cooperation, charity, etc. (Baumard et al. 2015; Norenzayan and Shariff 2008). Moralizing notions present in many Hindu scriptures, like Garuda Puran, Ramayana, and Mahabharata, encourage moral behaviors like non-violence, respect for Nature, etc. God's avatars like Rama and Krishna present the models of human behavior. Such types of institutional moralization, boosted with karma-phal theory, can be helpful in addressing environmental problems by sanctioning bad and endorsing good behaviors in Hinduism.

(c) Reformation of the practices that have deviated from the original concept and discontinuing the bad practices

Many religious practices that were relevant at their start have become harmful and irrelevant in changed scenarios or have diverted from their original objects due to various reasons. The practices that have diverted from their original concepts may be improved by their realignment with the DHARMA. For example, the common practices of animal sacrifice in Yajnas had no environmental or ethical concerns centuries ago when the human population was very low. However, on facing ethical challenges, these practices had been modified by replacing animals with fruits like coconut, cucurbits, or areca nuts. In these types of ritualized improvements, original concepts are retained but the practice is cleaned. 
Many wise traditions have lost their usefulness through undirected modification. The practices of nature worship have much potential for encouraging environmentally friendly behavior in people (Fowler-Smith 2009; Figure 2c). However, many such practices have been changed into cutting a twig from plants to worship it at home. Hindus generally avoid cutting trees of religious importance like Peepal, Banyan, and Neem; however, they get these cut from the members of other faiths (e.g., Muslims) when required. Rivers have a very important place in Hinduism, which are worshiped as a living god. However, offering the worshiping material and performing last rites at riverbanks are serious sources of water pollution in rivers. These practices can be improved by disseminating the original concepts with scientific explanation by gurus (Figure 3a,b). Electric cremation is not against the concept of last rites in Hinduism. However, it has not been adopted by people due to the lack of religious support and ritualization (Figure 3c,d). New rituals and theological discourses can easily be developed in Hinduism to adopt new technologies in religion (DeNapoli 2017; Srinivas 2004). Developing new rituals for such types of practices can help their popularization and adaptation among people.

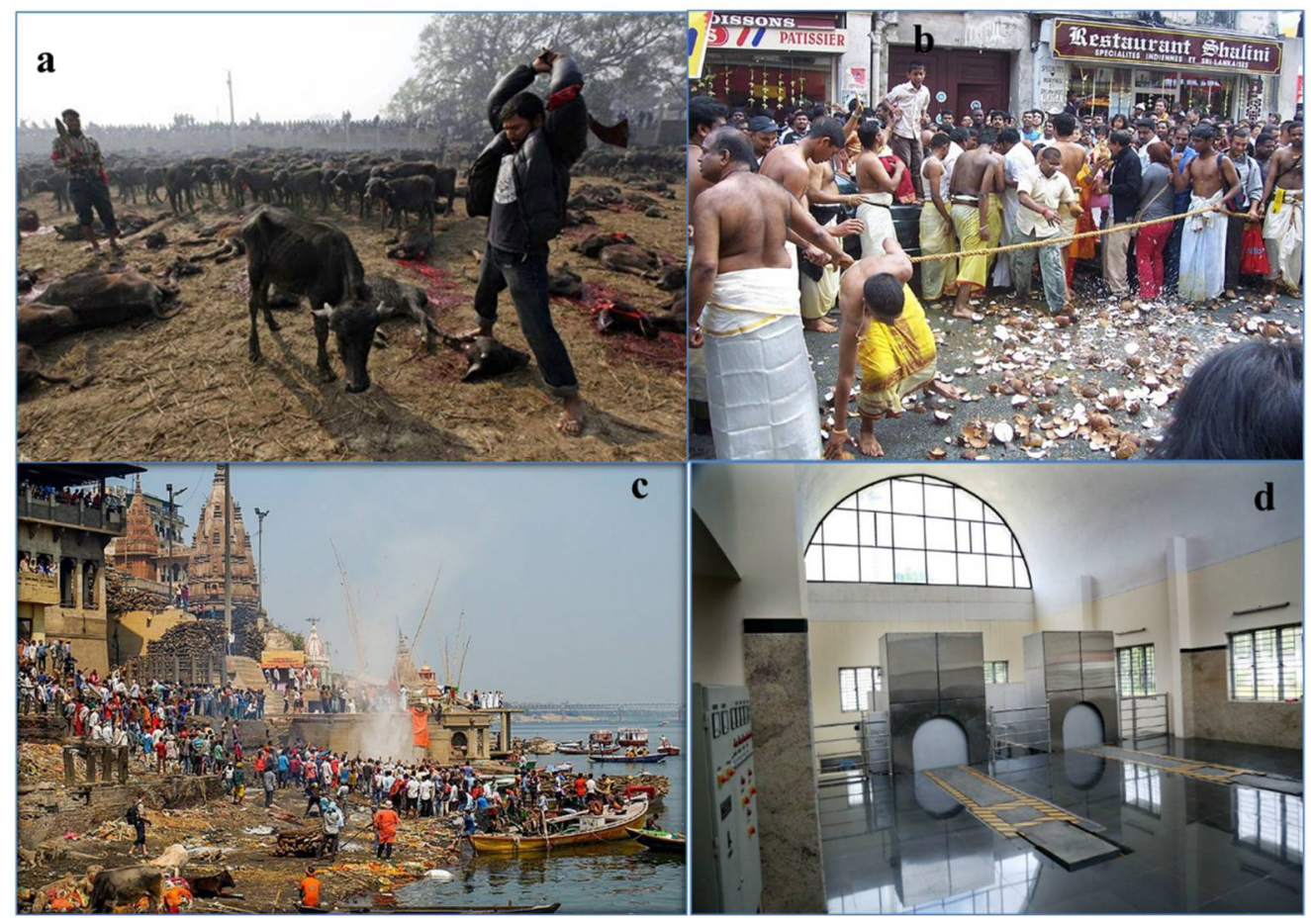

Figure 3. Plasticity in Hinduism provides an opportunity to start new traditions and modify or discontinue the traditions that are now irrelevant: $(\mathbf{a}, \mathbf{b})$, animal sacrifice, once common in Hinduism has been modified by using fruits like coconut, cucurbits, or areca nuts for sacrifice; (c,d), similarly, environmentally harmful cremation can be replaced by electric cremation through sensible interventions. Photo: from Wikimedia commons.

\section{Conclusions}

Global environmental emergencies need immediate actions from all possible sources ignoring all other conflicts of interest related to identity, faith, beliefs, ideology, history, etc. Realization of the non-dualism of self and Nature and behaving according to their dharma is difficult for most people. It is the responsibility of those who can realize it to watch and influence the behavior of others to uphold the DHARMA. Bhakti is the powerful religious tool in Hinduism that can moderate peoples' behavior to impart environmentally friendly practices. A wise coordination of gyan and bhakti can be a model for addressing environmental problems through religious pathways in Hinduism. 
Funding: This research did not receive any specific grant from funding agencies in the public, commercial, or not-for-profit sectors.

Institutional Review Board Statement: Not applicable.

Informed Consent Statement: Not applicable.

Data Availability Statement: No new data were created or analyzed in this study. Data sharing is not applicable to this article.

Conflicts of Interest: I declare no conflict of interest.

\section{Notes}

1 Note 1: Traditional monkey traps are large jars with narrow mouth chained to a pole. The jars are filled with grains, which can be grabbed through a small hole. The monkey's hand fits through the hole but his closed fist cannot. The monkey puts in his hands and clutches a handful of grains but he is unable to draw his fist out of the jar. He assumes himself caught though he can release himself by opening his hand. The monkey is not trapped in a real trap but by a false assumption.

\section{References}

Balcombe, Jonathan. 2009. Animal pleasure and its moral significance. Applied Animal Behaviour Science 118: 208-16. [CrossRef]

Baumard, Nicolas, Alexandre Hyafil, Ian Morris, and Pascal Boyer. 2015. Increased affluence explains the emergence of ascetic wisdoms and moralizing religions. Current Biology 25: 10-15. [CrossRef] [PubMed]

Chaplin, Jonathan. 2016. The global greening of religion. Palgrave Communications 2: 16047. [CrossRef]

Chauhan, Sheila, Sita Rama das, Martin Haigh, and Natalia Rita. 2010. Awareness vs intentionality: Exploring education for sustainable development in a British Hindu community. Sustainable Development 20: 361-71. [CrossRef]

Chauhan, Sheila, Sita Rama das, Martin Haigh, and Natalia Rita. 2009. Promoting education for sustainability in a Vaishnava Hindu community. Applied Environmental Education and Communication 8: 114-25. [CrossRef]

Cinner, Joshua. 2018. How behavioral science can help conservation. Science 362: 889-90. [CrossRef]

Dasgupta, Partha, and Veerabhadran Ramanathan. 2014. Pursuit of the common good. Nature 345: 1457-58. [CrossRef]

DeNapoli, Antoinette E. 2016. "Nature is our true friend": The Environmental Empathy of a Modern Female Guru in North India. Nidān 1: 32-68.

DeNapoli, Antoinette E. 2017. Dharm is technology": The theologizing of technology in the experimental Hinduism of renouncers in contemporary North India. International Journal of Dharma Studies 5: 18-54. [CrossRef]

Ducarme, Frédéric, and Denis Couvet. 2020. What does 'nature' mean? Palgrave Communications 6: 14. [CrossRef]

Ferry, Mathieu. 2020. What's India's Beef with Meat? Hindu Orthopraxis and Food Transition in India Since the 1980s. Sociological Forum. [CrossRef]

Fourat, Estelle, and Olivier Lepiller. 2017. Forms of food transition: Sociocultural factors limiting the diets' animalisation in France and India. Sociologia Ruralis 57: 41-63. [CrossRef]

Fowler-Smith, Louise. 2009. Hindu tree veneration as of mode of environmental encounter. Leonardo 42: 43-51. [CrossRef]

Godfray, H. Charles J., Paul Aveyard, Tara Garnett, Jim W. Hall, Timothy J. Key, Jamie Lorimer, Ray T. Pierrehumbert, Peter Scarborough, Marco Springmann, and Susan A. Jebb. 2018. Meat consumption, health, and the environment. Science 3616399: eaam5324. [CrossRef]

Grim, John, and Mary Evelyn Tucker. 2013. Ecology and Religion. Washington, DC: Island Press.

Grinde, Bjørn. 2004. Darwinian happiness: Can the evolutionary perspective on well-being help us improve society? World Futures 61: 317-29. [CrossRef]

Haigh, Martin. 2010. Education for a sustainable future: Strategies of the new Hindu religious movements. Sustainability 2: 3500-519. [CrossRef]

Hitzhusen, Gregory E., and Mary Evelyn Tucker. 2013. The potential of religion for Earth Stewardship. Frontiers in Ecology and the Environment 11: 368-76. [CrossRef]

IPCC. 2018. Global Warming of $1.5^{\circ} \mathrm{C}$ : An IPCC Special Report. Summary for Policymakers. Geneva: IPCC.

Jenkins, Willis, Evan Berry, and Luke Beck Kreider. 2018. Religion and Climate Change. Annual Review of Environment and Resources 43: 85-108. [CrossRef]

Jones, Constance, and James D. Ryan. 2006. Encyclopedia of Hinduism. New York: InfoBase Publishing.

Karthikeyan, Leelavathy, Venkatesan Madha Suresh, Vignesh Krishnan, Terry Tudor, and Vedha Varshini. 2018. The Management of Hazardous Solid Waste in India: An Overview. Environments 5: 103. [CrossRef]

Klostermaier, Klaus. 1985. Mokșa and Critical Theory. Philosophy East and West 35: 61-71. [CrossRef]

Lucia, Amanda. 2014. Innovative Gurus: Tradition and Change in Contemporary Hinduism. International Journal of Hindu Studies 18: 221-63. [CrossRef] 
Luthy, Tamara. 2019. Bhajan on the Banks of the Ganga: Increasing Environmental Awareness via Devotional Practice. Journal of Dharma Studies 1: 229-40. [CrossRef]

Ma, Wentao. 2016. The essence of life. Biology Direct 11: 49. [CrossRef] [PubMed]

Miller, David. 1977. The guru as the centre of sacredness. Studies in Religion/Sciences Religieuses 6: 527. [CrossRef]

Morrison, Mark, Roderick Duncan, and Kevin Parton. 2015. Religion does matter for climate change attitudes and behavior. PLoS ONE 108: e0134868. [CrossRef]

Nesse, Randolph M., and George C. Williams. 1996. Why We Get Sick: The New Science of Darwinian Medicine. New York: Vintage Books.

Norenzayan, Ara, and Azim F. Shariff. 2008. The origin and evolution of religious prosociality. Science 322: 58-62. [CrossRef]

Ravishankara, A. R., Liji M. David, Jeffrey R. Pierce, and Chandra Venkataraman. 2021. Outdoor air pollution in India is not only an urban problem. Proceedings of the National Academy of Sciences 117: 28640-44. [CrossRef]

Rigopoulos, Antonio. 2018. Guru, Hinduism. In Hinduism and Tribal Religions. Encyclopedia of Indian Religions. Edited by Pankaj Jain, Rita Sherma and Madhu Khanna. Dordrecht: Springer.

Roes, Frans L., and Michel Raymond. 2003. Belief in moralizing gods. Evolution and Human Behavior 24: 126-35. [CrossRef]

Rockström, Johan, Will Steffen, Kevin Noone, Asa Persson, F. Stuart Chapin III, Eric F. Lambin, Timothy M. Lenton, Marten Scheffer, Carl Folke, Hans Joachim Schellnhuber, and et al. 2009. A safe operating space for humanity. Nature 461: 472-75. [CrossRef]

Rust, Niki A., Lucy Ridding, Caroline Ward, Beth Clark, Laura Kehoe, Mano Dora, Mark J. Whittingham, Philip McGowan, Abhishek Chaudhary, Christian J. Reynolds, and et al. 2020. How to transition to reduced-meat diets that benefit people and the planet. Science of the Total Environment 718: 137208. [CrossRef]

Sans, Pierre, and Pierre Combris. 2015. World meat consumption patterns: An overview of the last fifty years 1961-2011. Meat Science 109: 106-11. [CrossRef] [PubMed]

Sathe, Yogesh, Pawan Gupta, Moqtik Bawase, Lok Lamsal, Falguni Patadia, and Sukrut Thipse. 2021. Surface and satellite observations of air pollution in India during COVID-19 lockdown: Implication to air quality. Sustainable Cities and Society 66: 102688. [CrossRef]

Sharma, Arvind. 2007. Advaita Vedānta: An Introduction. New Delhi: Motilal Banarsidass.

Shinde, Kiran A. 2011. "This is religious environment": Sacred space, environmental discourses, and environmental behavior at a Hindu pilgrimage site in India. Space and Culture 14: 448-63. [CrossRef]

Springmann, Marco, Michael Clark, Daniel Mason-D'Croz, Keith Wiebe, Benjamin Leon Bodirsky, Luis Lassaletta, Wim de Vries, Sonja J. Vermeulen, Mario Herrero, Kimberly M. Carlson, and et al. 2018. Options for keeping the food system within environmental limits. Nature 562: 519-25. [CrossRef]

Srinivas, Tulasi. 2004. Tradition in Transition: Globalisation, Priests, and Ritual Innovation in Neighbourhood Temples in Bangalore. Journal of Social and Economic Development 6: 57-75.

Steffen, Will, Johan Rockström, Katherine Richardson, Timothy M. Lenton, Carl Folke, Diana Liverman, Colin P. Summerhayes, Anthony D. Barnosky, Sarah E. Cornell, Michel Crucifix, and et al. 2018. Trajectories of the Earth system in the Anthropocene. Proceedings of the National Academy of Sciences 115: 8252-59. [CrossRef]

Suddendorf, Thomas. 2013. The Gap: The Science of What Separates Us from Other Animals. New York: Basic Books.

Taylor, Bron, Gretel Van Wieren, and Bernard Zaleha. 2016. The Greening of Religion Hypothesis Part Two: Assessing the Data from Lynn White, Jr, to Pope Francis. Journal for the Study of Religion, Nature and Culture 10: 306-78. [CrossRef]

Theobald, Douglas L. 2010. A Formal Test of the Theory of Universal Common Ancestry. Nature 465: 219-22. [CrossRef] [PubMed]

Tilman, David, and Michael Clark. 2014. Global diets link environmental sustainability and human health. Nature 515: 518-22. [CrossRef]

Tomalin, Emma. 2004. Bio-divinity and biodiversity: Perspectives on religion and environmental conservation in India. Numen 51: 265-95. [CrossRef]

Vohs, Kathleen D., Yajin Wang, Francesca Gino, and Michael I. Norton. 2013. Rituals Enhance Consumption. Psychological Science 24: 1714-21. [CrossRef] [PubMed] 